\title{
Contributions to the taxonomy, identification, and biogeography of Eriborus Förster, 1869 and Nepiesta Förster, 1869 (Hymenoptera: Ichneumonidae: Campopleginae)
}

\author{
Z. VAS \\ Zoltán Vas, Hungarian Natural History Museum, Department of Zoology, Hymenoptera Collection, \\ H-1088 Budapest, Baross u. 13., Hungary.E-mail:vas.zoltan@nhmus.hu
}

\begin{abstract}
Eriborus mirabilis sp. nov. is described from Papua New Guinea, and the first identification key to the Australasian species of Eriborus Förster, 1869 is provided. Nepiesta cruella sp. nov. is described from Jordan, the female of Nepiesta tibialis Horstmann, 1977 is described for the first time, and an updated identification key to all known Nepiesta Förster, 1869 species is given. Additionally, the first records of Eriborus obscuripes Horstmann, 1987 from Romania, Eriborus terebrator Aubert, 1960 from Hungary and Spain, Nepiesta mandibularis (Holmgren, 1860) from Hungary and Romania, Nepiesta rufocincta Strobl, 1904 from Romania, and Nepiesta tibialis Horstmann, 1977 from Turkmenistan are reported.
\end{abstract}

Keywords. Eriborus mirabilis sp. nov., Nepiesta cruella sp. nov., Nepiesta tibialis, species description, identification key, new records, Australian realm, Palaearctic realm, Imre Loksa.

\section{INTRODUCTION}

H riborus Förster, 1869 is a moderately species rich genus of the family Ichneumonidae, subfamily Campopleginae with 56 valid species worldwide, including the presently described new species; it is most diverse in the Oriental and Eastern Palaearctic regions ( $\mathrm{Yu}$ et al. 2012). Regarding Eriborus, the biogeographical scope of this work is the Australian (Australasian) realm, including Australia, New Guinea, New Zealand and the surrounding islands (such as New Caledonia or Vanuatu) eastwards from Wallace's line; Fiji and Samoa Islands are also considered here (Rueda et al. 2013), though sometimes these are assigned to the Oceanic realm (see e.g. Olson et al. 2001, Yu et al. 2012). There are eight Eriborus species known from the Australasian region, including the presently described Eriborus mirabilis sp. nov.; one of these, Eriborus molestae (Uchida, 1933), is an Eastern Palaearctic (Japan, Korea) and Nearctic (USA) species, introduced to Australia (Yu et al. 2012). Eriborus loculosus (Vachal, 1907) and Eriborus cryptoides (Vachal,
1907) are known from New Caledonia, Eriborus epiphyas Paull \& Austin, 2006 from Australia, Eriborus iavilai (Cheesman, 1936) from Australia, New Caledonia and Vanuatu, and Eriborus tutuilensis (Fullaway, 1940) from Fiji and American Samoa ( $\mathrm{Yu}$ et al. 2012). Besides Eriborus mirabilis sp. nov. only one species, Eriborus anomalus (Tosquinet, 1903) is known from Papua New Guinea, as well as from the whole island of New Guinea (Yu et al. 2012). Since the majority of known species of the genus is tropical and/or subtropical, most probably several yet undescribed species occur in Australasia as well.

Nepiesta Förster, 1869 is small genus of the family Ichneumonidae, subfamily Campopleginae, with 12 valid species worldwide, including the presently described Nepiesta cruella sp. nov. All known Nepiesta species occur in the Palaearctic realm; most species are known only from the Western Palaearctic region, while Nepiesta rasnitsyni Kasparyan, 2011 is known only from the Eastern Palaearctic region, and Nepiesta mandibularis (Holmgren, 1860) from both regions 
(Yu et al. 2012). Nepiesta tibialis Horstmann, 1977 was described and still known only by a male specimen from the material of the Hungarian Natural History Museum (HNHM, Budapest) (Horstmann, 1977). In the material of HNHM, recently a female specimen of Nepiesta tibialis Horstmann, 1977 was found, collected in the same location, at the same date, and by the same collector as the holotype male (this female specimen missed Horstmann's attention, most probably because it was in a different drawer among the unsorted, unidentified material). As Horstmann's (1977) original description is rather short, a more detailed re-description of the species is given in this work, representing also the first description of the female.

\section{MATERIAL AND METHODS}

The taxonomical and faunistical results of this paper were yielded during the ongoing identification process of Ichneumonidae material housed in the HNHM. Type specimens of the presently described Eriborus mirabilis sp. nov. were collected by Imre Loksa (1923-1992), a pedozoologist and former head of the Department of Systematic Zoology and Ecology at Eötvös Loránd University (Budapest, Hungary) during his expedition to Papua New Guinea in 1968.

Taxonomy and nomenclature follow $\mathrm{Yu} \&$ Horstmann (1997), and Yu et al. (2012); complete nomenclatural history and list of synonym taxa are not repeated here, since they were given in detail in these works. The morphological terminology applied in this paper is primarily based on Gauld (1991) and Gauld et al. (1997); however, in some cases, especially about of wing veins, the corresponding terminology of Townes (1969) is also indicated. The identifications and the provided key are based on Tosquinet (1903), Cameron (1907), Vachal (1907), Cheesman (1936), Fullaway (1940), Townes et al. (1961), Šedivý (1963), Momoi (1970), Townes (1970), Horstmann (1973, 1977, 1987), Aubert (1977), Kasparyan (1981, 2011), Jonathan (1999), Paull \& Andrew (2006), Khalaim \& Kasparyan (2007), Choi \& Lee (2010), and on checking the relevant type material. Distributional records of species were checked and traced through the database of $\mathrm{Yu}$ et al. (2012). The specimens were identified and examined by the author using a Nikon SMZ 645 stereoscopic microscope, and are deposited in the Hymenoptera Collection of HNHM. Photos were taken with Nikon D5200 and Nikon AF Micro Nikkor $60 \mathrm{~mm}$ lens and MitutoyoM Plan Apo 5X microscope lens. Exposures were stacked in ZereneStacker 1.04, post image work was done with ImageJ $1.52 \mathrm{c}$ and Photoshop CS5.

\section{RESULTS}

\section{Taxonomy}

\section{Subfamily: Campopleginae Förster, 1869 Genus: Eriborus Förster, 1869}

Type species. Campoplex perfidus Gravenhorst, 1829; designation by Morley (1913).

\section{Eriborus mirabilis sp. nov.}

\section{(Figure 1)}

Material examined. Holotype: female, Papua New Guinea [on label: New Guinea /NE/], Mt. Wilhelm, Field Station, 20.IX.1968, leg. I. Loksa, No. NG-M.R. 32; specimen card-mounted, right antenna damaged; Id. No. HNHM-HYM 153086. Paratype: female, same locality, date, collector; specimen card-mounted; Id. No. HNHM-HYM 153087. [The Mt. Wilhelm Field Station mentioned on the label was established in Chimbu Province, Mt. Wilhelm, Pindaunde Valley, near Lake Aunde, $5^{\circ} 47^{\prime} 26.9^{\prime \prime S}$ 14503'29.2"E, ca. $3500 \mathrm{~m}$ a.s.l.]. The holotype and the paratype are deposited in the Hymenoptera Collection of HNHM (Budapest, Hungary).

Diagnosis. The new species can easily be distinguished from all other Australasian species of the genus by its elongated metasomal tergites (second tergite $2.3 \times$ as long as its apical width), which, from third tergite onwards, are distinctly excised medioapically, and by its unique coloration: ivory yellow pterostigma, mainly orange legs, more or less distinct faint bluish reflection on lateral parts of head and mesosoma. 


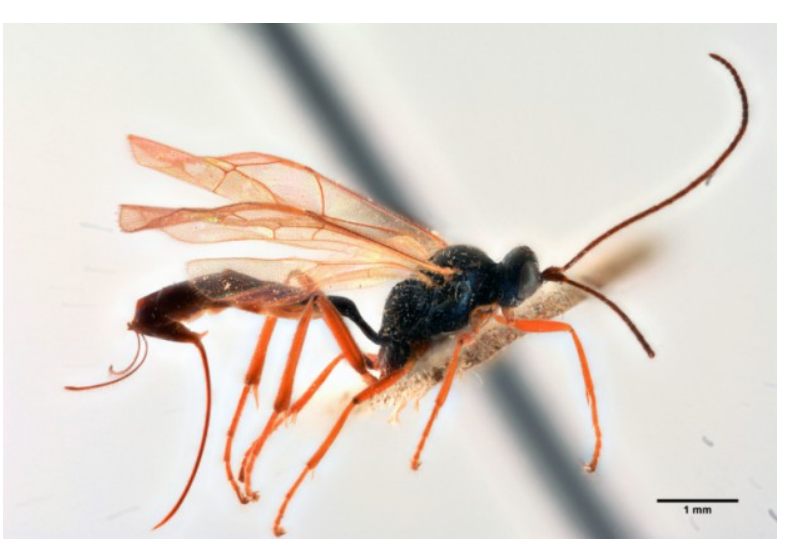

Figure 1. Holotype of Eriborus mirabilis sp. nov., female, lateral habitus (photo: Z. Soltész, HNHM).

Description. Female (Fig. 1). Body length $c a$. $5.5 \mathrm{~mm}$, fore wing length $c a .4 \mathrm{~mm}$.

Head. Antenna with 27 flagellomeres; first flagellomere long and slender, $c a .4 .5 \times$ as long as apically wide; preapical flagellomeres slightly longer than wide. Head transverse, granulate to finely granulate with relatively long and scattered whitish hairs. Ocelli small, ocular-ocellar distance $1.8-1.9 \times$ as long as ocellus diameter, posterior ocellar distance as long as or slightly shorter than ocellus diameter. Inner eye orbits weakly indented, parallel. Gena (temple) shinier than other parts of head, wide, weakly narrowed behind eye, in dorsal view about as long as eye width; in lateral view, at the level of ventral margin of eye, gena longer than basal width of mandible. Occipital carina complete, almost straight, reaching hypostomal carina before mandibular base; hypostomal carina normal, not elevated. Malar space relatively long, $0.8-0.9 \times$ as long as basal width of mandible. Face and clypeus almost flat in profile, granulate; face matt, clypeus slightly shinier. Clypeus very weakly separated from face, apical margin weakly convex. Lower margin of mandible with moderately wide flange from teeth toward base, mandibular teeth of equal length.

Mesosoma. Mesosoma with short, greyish hairs; hairs denser on dorsal parts, sparser on lateral parts; lateral parts shinier than dorsal parts. Pronotum almost entirely granulate, lower corner with few, weak transverse wrinkles. Mesoscutum granulate, convex in profile, $1.1 \times$ as long as wide; notaulus not developed. Scuto-scutellar groove wide, deep, very finely granulate to smooth. Scutellum granulate, convex in profile, without lateral carina. Mesopleuron finely granulate; speculum very finely sculptured to almost smooth. Pleural and ventral part of epicnemial carina complete, strong; transverse part (i.e. part at the level of sternaulus running through the epicnemium to the ventral edge of pronotum) absent; pleural part obliquely bent to anterior margin of mesopleuron reaching it below its middle height; ventral part of epicnemial carina slightly elevated. Sternaulus indistinct. Posterior transverse carina of mesosternum complete. Metanotum finely granulate. Metapleuron very finely granulate; juxtacoxal carina absent; submetapleural carina complete. Pleural carina of propodeum strong; propodeal spiracle small, short oval, separated from pleural carina by about its length. Propodeum granulate, long, its apex lengthened above hind coxa, reaching about one third of length of hind coxa; propodeal carinae distinct. Area basalis small, triangular, its basal width subequal to its length, its apical tip connected to the base of area superomedia by a single median carina about as long as area basalis. Area superomedia longer than wide, lateral carinae very weakly constricted apically, almost parallel; area superomedia apically opened, confluent with area petiolaris. Costula (section of anterior transverse carina between lateromedian and lateral longitudinal carinae) strong, complete, connecting to lateral margin of area superomedia before its middle.

Fore wing without areolet, intercubitus (2rs- $m$ ) ca. $0.5 \times$ as long as abscissa of $M$ between intercubitus and second recurrent vein $(2 m-c u)$; distal abscissa of $R s$ straight, apically weakly curved toward $R$; distal abscissa of $M$ weakly pigmented; nervulus $(\mathrm{cu}-a)$ almost interstitial to very weakly postfurcal, inclivous; postnervulus (abscissa of $C u 1$ between $1 m-c u$ and $C u 1 a+$ $\mathrm{Cu} 1 \mathrm{~b}$ ) intercepted above its middle by $\mathrm{Cu} 1 \mathrm{a}$; lower external angle of second discal cell acute (ca. $70^{\circ}$ ). Hind wing with nervellus (cu-a + abscissa of $C u 1$ between $M$ and $c u-a$ ) weakly reclivous, not intercepted; discoidella (distal abscissa of $\mathrm{Cu}$ ) not connected to nervellus, very weak, not pigmented, spectral. 
Legs rather long and slender. Coxae finely granulate. Hind femur long, slender, $c a$. $6 \times$ as long as high. Inner spur of hind tibia longer than outer spur, inner spur ca. $0.45-0.50 \times$ as long as hind basitarsus. Hind basitarsus with a midventral row of closely spaced, short hairs (appearing as a darker, more or less scaly, inconspicuous line). Tarsal claws relatively long, slightly to distinctly longer than arolium, with few weak and small basal pecten.

Metasoma. Metasoma (not including ovipositor) $c a .1 .3-1.4 \times$ as long as combined length of head and mesosoma, compressed, very finely granulate to finely shagreened, rather shiny, with scattered, short, whitish hairs. First tergite long, narrow, $c a .3 \times$ as long as its apical width, with distinct, deep glymma; dorsomedian carina of first tergite indistinct; petiolus smooth, postpetiolus very finely granulate. Second tergite long, narrow, about as long as first tergite, $2.3 \times$ as long as its apical width; thyridium oval, its distance from basal margin of tergite $1.5 \times$ as long as its length. Third tergite $1.3-1.4 \times$ as long as its apical width. Epipleurum of second and third tergites separated by a crease. Posterior margin of third and following tergites medially concave, distinctly roundly excised, seventh tergite strongly excised. Ovipositor sheath $1.0-1.1 \times$ as long as hind tibia $(2 \times$ as long as first tergite, $3 \times$ as long as apical depth of metasoma, $c a$. $0.5 \times$ as long as metasoma, $c a$. $0.3 \times$ as long as body length), ovipositor upcurved, dorsal preapical notch distinct, tip narrowed, acute.

Colour. Head and mesosoma predominantly black with a more or less distinct faint bluish reflection on lateral parts; antenna brown to light brown, scapus and pedicellus ventrally yellowish brown; head black except yellow palpi and mandibles, mandibular teeth reddish brown; mesosoma black except pale yellow tegula. Metasoma: first tergite black; second tergite black, apical margin narrowly brownish; third tergite basally blackish, apically brown; from third tergite onwards, tergites brown to reddish brown; ovipositor sheath brown. Wings hyaline, wing veins light brown, pterostigma ivory yellow. Fore leg: coxa dull yellow; trochanter and trochantellus yellow; femur, tibia, and tarsus light orange.
Middle leg: coxa reddish to yellowish brown; trochanter and trochantellus yellow; femur, tibia, and tarsus orange. Hind leg: coxa black to dark brown; trochanter brown; trochantellus yellow; femur orange, narrowly and faintly more or less darkened basally; tibia orange, basally very narrowly darkened; tarsus orange, last tarsomere brownish.

Male. Unknown.

Distribution. Currently known from Papua New Guinea (Mount Wilhelm).

Ecology. No host is known. The new species might be a koinobiont endoparasitoid of lepidopterous hosts, similarly to other Eriborus species with known hosts.

Etymology. The specific epithet "mirabilis" is a Latin adjective (masculine gender, nominative case) meaning marvellous, wonderful, admirable, remarkable; it refers to the extraordinary colouration of the new species.

\section{Genus: Nepiesta Förster, 1869}

Type species. Nepiesta subclavata Tomson, 1887.

\section{Nepiesta cruella sp. nov.}

(Figure 2)

Material examined. Holotype: female, Jordan, 6.IV.1956, leg. J. Klapperich; specimen cardmounted, left antenna damaged, right middle leg missing; Id. No. HNHM-HYM 153101. The holotype is deposited in the Hymenoptera Collection of HNHM (Budapest, Hungary).

Diagnosis. The new species belongs to the morphological group of Nepiesta species characterised by ventrally flattened hind trochantellus and distinctly shortened hind basitarsus [this morphological group consists of the species previously included in the genus Eripternus Förster, 1869 in Šedivý (1963) and Kasparyan (1981), now considered a junior synonym of Nepiesta $(\mathrm{Yu}$ \& Horstmann 1997)]. Nepiesta cruella sp. nov. 
can easily be distinguished from all other species of this morphological group - namely Nepiesta tarsalis (Szépligeti, 1911) and Nepiesta atrator (Aubert, 1977) - by its entirely reddish middle and hind femora and tibiae (at least middle and hind femora are almost entirely black in both other species). Additionally, the new species differs from Nepiesta tarsalis (Szépligeti, 1911) by its black tegula and having the lower mandibular tooth longer than the upper, and from Nepiesta atrator (Aubert, 1977) by its stouter second tergite and having the nervellus intercepted below middle.

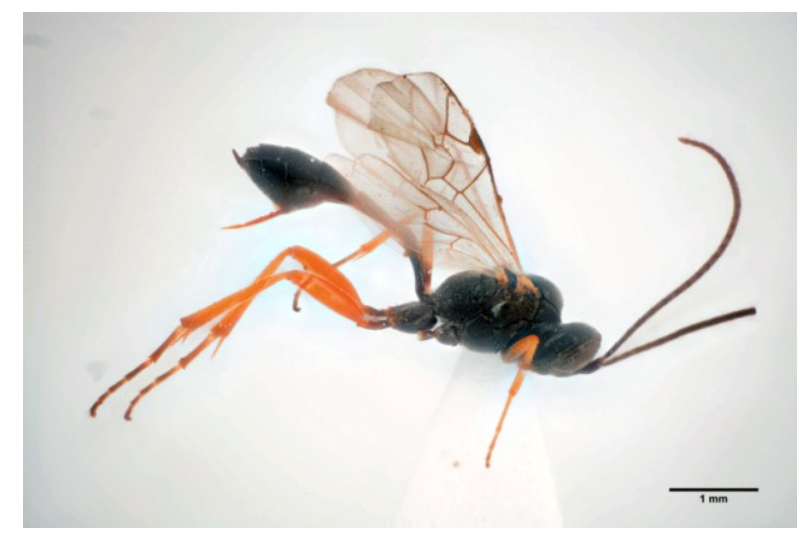

Figure 2. Holotype of Nepiesta cruella sp. nov., female, lateral habitus (photo: T. Németh, HNHM).

Description. Female (Fig. 2). Body length ca 5 $\mathrm{mm}$, fore wing length ca $4 \mathrm{~mm}$.

Head. Antenna with 26 flagellomeres; first flagellomere long and slender, $c a .4 \times$ as long as wide apically; preapical flagellomeres slightly longer than wide. Head with short and scattered, greyish hairs, transverse, granulate, distinctly and densely punctate, punctures separated from each other by usually less than a puncture diameter. Ocelli small, ocular-ocellar distance $1.6-1.7 \times$ as long as ocellus diameter, posterior ocellar distance $1.7 \times$ as long as ocellus diameter. Inner eye orbits slightly indented, parallel. Gena (temple) wide, not narrowed behind eye, in dorsal view about as long as eye width. Occipital carina bent outward ventrally, reaching hypostomal carina at mandible base, extreme ventral part obsolescent; hypostomal carina slightly elevated. Malar space $0.6 \times$ as long as basal width of mandible. Face and clypeus weakly convex in profile, and strongly, densely punctate. Face coarsely granulate, matt. Clypeus wide, shinier than face, dorsal part finely granulate, ventral part almost smooth, punctures stronger than on face, apical margin convex. Mandible rather strong and long, basal half strongly, densely punctate, lower margin without flange, lower tooth distinctly longer than upper tooth.

Mesosoma. Mesosoma with short, greyish hairs; hairs denser on dorsal parts, sparser on lateral parts. Dorsal part of pronotum densely punctate on finely granulate surface, punctures separated from each other by usually less than a puncture diameter, ventral part of pronotum with strong transverse wrinkles on smoother, shinier surface. Mesoscutum finely granulate, and densely, coarsely punctate, punctures separated from each other by usually less than a puncture diameter; mesoscutum convex in profile, about as long as wide; notaulus not developed. Scuto-scutellar groove wide, deep. Scutellum densely punctate on granulate surface, punctures separated from each other by usually less than a puncture diameter; scutellum convex in profile, without lateral carina. Mesopleuron densely punctate on granulate to finely granulate surface, punctures separated from each other by usually less than a puncture diameter; anterior two-third of speculum shagreened, posterior third smooth. Pleural and ventral part of epicnemial carina complete, strong; transverse part (i.e. part at the level of sternaulus running through the epicnemium to the ventral edge of pronotum) absent; pleural part obliquely bent to anterior margin of mesopleuron reaching it below its middle height; ventral part of epicnemial carina slightly elevated. Sternaulus indistinct. Posterior transverse carina of mesosternum complete. Metanotum granulate. Metapleuron densely punctate on granulate surface, punctures separated from each other by usually less than a puncture diameter; juxtacoxal carina indistinct; submetapleural carina complete. Pleural carina of propodeum strong; propodeal spiracle small, circular, separated from pleural carina by about $2 \times$ its length. Anterior third of propodeum densely punctate on granulate surface, punctures separated from each other by usually less than a puncture 
diameter; posterior two-third of propodeum granulate with strong, dense irregular wrinkles; propodeal carinae only partly developed. Area basalis very small, trapezoidal. Area superomedia narrow, longer than wide, its lateral carinae weakly divergent apically; area superomedia apically opened, confluent with area petiolaris. Costula (section of anterior transverse carina between lateromedian and lateral longitudinal carinae) indistinct.

Fore wing with relatively large, tetragonal areolet, posterior half of $3 r s-m$ weakly pigmented, $2 r s-m$ about as long as abscissa of $M$ between $2 r s-$ $m$ and second recurrent vein $(2 m-c u)$; distal abscissa of $R s$ straight, apically weakly curved toward $R$; distal abscissa of $M$ weakly pigmented; nervulus $(\mathrm{cu}-a)$ postfurcal by about its width, slightly inclivous; postnervulus (abscissa of $\mathrm{Cu} 1$ between $1 m-c u$ and $C u 1 \mathrm{a}+C u 1 b)$ intercepted below its middle by $C u 1 \mathrm{a}$; lower external angle of second discal cell almost right-angle. Hind wing with nervellus ( $c u-a+$ abscissa of $C u 1$ between $M$ and $c u-a$ ) intercepted little below middle by discoidella (distal abscissa of $\mathrm{Cu} 1$ ), discoidella very weakly pigmented to spectral.

Coxae finely granulate with weak, dense punctures. Hind trochantellus distinctly flattened from below. Hind femur rather stout, $c a .4 \times$ as long as high. Inner spur of hind tibia longer than outer spur, inner spur $c a$. $0.6 \times$ as long as hind basitarsus. Hind basitarsus shortened, distinctly shorter than middle basitarsus. Tarsal claws small, thin, about as long as arolium, without basal pecten.

Metasoma. Metasoma finely to very finely granulate with short, dense, greyish hairs. First tergite long, narrow, $c a .3 \times$ as long as its apical width, without glymma; dorsomedian carina of first tergite not developed; petiolus smooth, postpetiolus very finely granulate. Second tergite $1.3 \times$ as long as its apical width; thyridium absent. Third tergite about as long as its apical width. Epipleurum of second and third tergites separated by a crease. Ovipositor sheath short, about as long as apical depth of metasoma; ovipositor straight, dorsal preapical notch distinct, tip acute.

Colour. Antenna black to dark brown. Head black except brownish middle of mandibles and light brown palpi. Mesosoma, including tegula, black. Metasoma black. Wings hyaline, wing veins brown, pterostigma brown. Fore leg: coxa blackish; trochanter dark brown, trochantellus brown; femur light reddish, basal one-sixth brown; tibia light reddish; tarsus light reddish, apical tarsomeres brownish. Middle leg: coxa blackish; trochanter dark brown, trochantellus brown; femur reddish, basal one-sixth brown; tibia reddish; tarsus brownish. Hind leg: coxa black; trochanter dark brown, trochantellus dark brown to brown; femur entirely reddish; tibia reddish, apically slightly darkened; tarsus brownish, extreme basal parts of tarsomeres yellowish.

Male. Unknown.

Distribution. Currently known from Jordan.

Ecology. No host is known. The only other Nepiesta species with known hosts, Nepiesta tarsalis (Szépligeti, 1911), is a koinobiont endoparasitoid of the leaf beetle Colaphellus sophiae (Schaller, 1783) (Coleoptera: Chrysomelidae) (Müller 1950).

Etymology. The specific epithet "cruella" is derived from the name Cruella de Vil, a fictional antagonist character created by the English author Dorothy Gladys Smith in her novel, The Hundred and One Dalmatians, in 1956. The new species shows a superficial resemblance in colouration (black body with reddish legs) to Cruella de Vil's usual clothing in her animated and live-action adaptations (black dress with red gloves and shoes). Another reason of this choice was to dignify Dorothy Gladys Smith's creative pun in naming this villain character, which name, I believe, fits very well to an ichneumon wasp, too. The specific epithet is a proper noun in apposition, its ending not to be changed.

\section{Nepiesta tibialis Horstmann, 1977}

(Figure 3)

Material examined. Male (holotype), Jordan [on label: O. Jordan], Jordan Valley [on label: Jordantal], Arda Road, 600 m, 8.III.1958, leg. J. 
Klapperich, specimen pinned, Id. No. HNHMHYM 100288. - Female, same location, date, and collector, specimen pinned, Id. No. HNHM-HYM 153102. - The holotype male specimen and the below described female specimen are deposited in the Hymenoptera Collection of HNHM (Budapest, Hungary). [Note that in the original description of the species, the year of the collection of the holotype specimen is erroneously indicated as 1959 (Horstmann 1977); the correct date from the label is the one given here.]

Diagnosis. Nepiesta tibialis Horstmann, 1977 is characterised by normal (not flattened from below) hind trochantellus and not shortened hind basitarsus (hind basitarsus not shorter than middle basitarsus). Nepiesta tibialis Horstmann, 1977 is most similar in colouration to Nepiesta mandibularis (Holmgren, 1860), as both species have yellow tegula, yellowish pterostigma, and entirely to predominantly dark metasoma and hind femur. Nepiesta tibialis Horstmann, 1977 can be easily distinguished from Nepiesta mandibularis (Holmgren, 1860) by the colouration of the hind tibia: externo-medially it is distinctly creamy yellowish in Nepiesta tibialis Horstmann, 1977, while reddish brown in Nepiesta mandibularis (Holmgren, 1860).

Description. Female (Fig. 3). Body length $c a$. $5 \mathrm{~mm}$, fore wing length ca $4 \mathrm{~mm}$.

Head. Antenna with 23 flagellomeres; first flagellomere $c a .3 .5 \times$ as long as wide apically; preapical flagellomeres longer than wide. Head with dense, greyish hairs, transverse, granulate and distinctly, densely punctate, punctures separated from each other by usually less than a puncture diameter. Ocelli small, ocular-ocellar distance $1.6 \times$ as long as ocellus diameter, posterior ocellar distance about $2 \times$ as long as ocellus diameter. Inner eye orbits slightly indented, parallel. Gena (temple) wide, weakly narrowed behind eye, in dorsal view about $0.8 \times$ as long as eye width. Occipital carina reaches hypostomal carina before mandible base; hypostomal carina slightly elevated. Malar space only slightly shorter than basal width of mandible. Face and clypeus weakly convex in profile, and strongly, densely punctate.

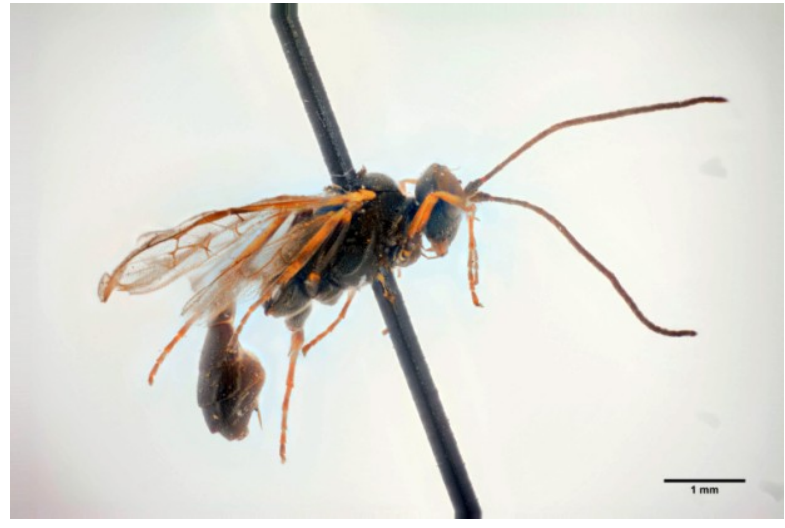

Figure 3. Female of Nepiesta tibialis Horstmann, 1977, Id. No. HNHM-HYM 153102, lateral habitus (photo: T. Németh, HNHM).

Face coarsely granulate, matt. Clypeus wide, shinier than face, dorsal part finely granulate, ventral part almost smooth, punctures stronger than on face, apical margin convex. Mandible rather long, upper tooth slightly longer than lower tooth.

Mesosoma. Mesosoma with short, dense, greyish hairs. Dorsal part of pronotum densely punctate on finely granulate surface, punctures separated from each other by usually less than a puncture diameter, ventral part of pronotum with strong transverse wrinkles on smoother, shinier surface. Mesoscutum finely granulate, and densely, coarsely punctate, punctures separated from each other by usually less than a puncture diameter; mesoscutum convex in profile, about as long as wide; notaulus not developed. Scuto-scutellar groove wide, deep. Scutellum densely punctate on granulate surface, punctures separated from each other by usually less than a puncture diameter; scutellum convex in profile, without lateral carina. Mesopleuron densely punctate on granulate to finely granulate surface, punctures separated from each other by usually less than a puncture diameter; speculum very finely granulate to smooth. Pleural and ventral part of epicnemial carina complete, strong; transverse part (i.e. part at the level of sternaulus running through the epicnemium to the ventral edge of pronotum) absent; pleural part obliquely bent to anterior margin of mesopleuron reaching it below its middle height; ventral part of epicnemial carina slightly elevated. Sternaulus indistinct. Posterior transverse carina 
of mesosternum complete. Metanotum granulate. Metapleuron densely punctate on granulate surface, punctures separated from each other by usually less than a puncture diameter; juxtacoxal carina indistinct; submetapleural carina complete. Pleural carina of propodeum basally strong, apically weak; propodeal spiracle small, circular, separated from pleural carina by about its length. Anterior half of propodeum densely punctate on granulate surface, punctures separated from each other by usually less than a puncture diameter; posterior half granulate with mostly transverse wrinkles; propodeal carinae only partly developed, rather weak. Area basalis very small, trapezoidal. Area superomedia finely granulate, longer than wide, its lateral carinae weakly convergent posteriorly, apically weakly closed. Costula (section of anterior transverse carina between lateromedian and lateral longitudinal carinae) short, indistinct, connecting to lateral margin of area superomedia before its middle. Apical part of area superomedia and area petiolaris with transverse wrinkles.

Fore wing without areolet, $2 r s-m$ longer than abscissa of $M$ between $2 r s-m$ and second recurrent vein $(2 m-c u)$; distal abscissa of $R s$ straight, apically weakly curved toward $R$; distal abscissa of $M$ weakly pigmented; nervulus (cu- $a$ ) interstitial, straight; postnervulus (abscissa of $\mathrm{Cu} 1$ between $1 m-c u$ and $C u 1 \mathrm{a}+\mathrm{Cu} 1 \mathrm{~b})$ intercepted at its middle by $C u 1 \mathrm{a}$; lower external angle of second discal cell almost right-angle. Hind wing with nervellus (cu- $a+$ abscissa of $C u 1$ between $M$ and $c u-a$ ) intercepted distinctly below middle by discoidella (distal abscissa of $C u 1$ ), discoidella very weakly pigmented to spectral.

Coxae finely granulate with weak, dense punctures. Hind trochantellus normal, not flattened from below. Hind femur rather stout, $c a .4 \times$ as long as high. Inner spur of hind tibia longer than outer spur, inner spur ca $0.6 \times$ as long as hind basitarsus. Hind basitarsus as long as middle basitarsus. Tarsal claws small, thin, about as long as arolium, without basal pecten.

Metasoma. Metasoma granulate to finely granulate with short, dense, greyish hairs. First tergite finely granulate, narrow, $\mathrm{ca} .2 .5 \times$ as long as its apical width, without glymma, dorsomedian carina not developed. Second tergite about as long as its apical width; thyridium absent. Third and following tergites shorter than apical width. Epipleurum of second and third tergites separated by a crease. Ovipositor sheath short, about as long as apical depth of metasoma; ovipositor straight, dorsal preapical notch distinct, tip acute.

Colour. Antenna black to dark brown. Head black; mandibles mainly yellow, basally black, teeth brownish, palpi light brown. Mesosoma black except yellow tegula. Metasoma black, except very narrow yellowish patches at apical edges of first and second tergites. Wings hyaline, wing veins brown, pterostigma yellowish. All coxae, trochanters and trochantelli black, with narrow yellowish patches on trochantelli. Fore femur yellowish, basal half predominantly black; middle and hind femur black, apically narrowly yellowish. Fore tibia yellowish; middle tibia yellowish brown; hind tibia basally and externomedially creamy yellow, subbasally, interno-medially and apically dark brown. All tarsi yellowish brown to brown.

Male. Similar to female in all characters described above, except whole speculum very finely granulate, and metasoma slightly slenderer, first tergite $3 \times$ as long as its apical width, second tergite $1.2 \times$ as long as its apical width; antennae of the holotype male are broken, number of flagellomeres unknown; see also the original description (Horstmann 1977).

Distribution. Currently known from Jordan and from Turkmenistan (see below in Biogeography section).

\section{Identification}

An identification key to the Australasian species of Eriborus is provided below. Since four out of the eight Australasian species are known only by females, this key works for females; hence, Eriborus cryptoides (Vachal, 1907), a New Caledonian species described and known by male only, is not considered here. Distributional information is given in brackets. 
1. Pterostigma ivory yellow [Papua New Guinea]

- Pterostigma entirely or predominantly brown 2

2. Hind coxa yellowish to light yellowish or reddish brown ...3

- Hind coxa black or very dark brown . .4

3. Petiolus entirely reddish. Eriborus iavilai (Cheesman, 1936) [Australia, New Caledonia, Vanuatu]

- Petiolus almost entirely black..................Eriborus tutuilensis (Fullaway, 1940) [Fiji, American Samoa]

4. Metasoma entirely black, hind femur almost entirely blackish...........................Eriborus loculosus (Vachal, 1907) [New Caledonia]

- Metasoma not entirely black, hind femur not blackish .......5

5. Metasoma basally black, dark brownish in the middle, apically black ................ Eriborus molestae (Uchida, 1933) [Australia, introduced]

- Metasoma apically reddish brown, not black

6. Second tergite slightly shorter than its apical width Eriborus epiphyas Paull et Austin, 2006 [Australia]

- Second tergite $1.5 \times$ as long as its apical width

Eriborus anomalus (Tosquinet, 1903) [Papua New Guinea]

An identification key to all known species of Nepiesta is provided below. This key is largely based on Horstmann (1973); however, updated and completed with the subsequently described species in Horstmann (1977), Kasparyan (2011), and in present study, and with Nepiesta tarsalis (Szépligeti, 1911) and Nepiesta atrator (Aubert, 1977), which species were previously included in the genus Eripternus, now considered a junior synonym of Nepiesta (Yu \& Horstmann 1997).

1. Hind basitarsus distinctly shorter than middle basitarsus, hind trochantellus distinctly flattened from below...............2

- Hind basitarsus not shorter than middle basitarsus, hind trochantellus normal, not flattened from below

... 4

2. Tegula yellow, upper mandibular tooth longer than lower tooth................................ Nepiesta tarsalis (Szépligeti, 1911)

- Tegula black, upper mandibular tooth shorter than lower tooth.

3. Hind femur entirely to almost entirely black.

............................................ Nepiesta atrator (Aubert, 1977)

- Hind femur entirely reddish..............Nepiesta cruella sp. nov.

4. Tegula black or dark brown.

- Tegula yellow
5. Metasoma basally and apically black, middle tergites of metasoma widely reddish, second tergite distinctly longer than its apical width ........... Nepiesta rufocincta Strobl, 1904

- Metasoma entirely or predominantly dark ............................6

6. Area superomedia about as long as area petiolaris, second tergite about as long as its apical width in females, longer than its apical width in males.....

Nepiesta jugicola Strobl, 1904

- Area superomedia distinctly shorter than area petiolaris, second tergite longer than its apical width in both sexes........ Nepiesta robusta Schmiedeknecht, 1909

7. Hind femur predominantly reddish, middle tergites of metasoma widely reddish ....................................................8

- Hind femur predominantly black, metasoma entirely dark or dark with brownish bands ................................................9

8. Antenna with 21 flagellomeres, area superomedia $1.5 \times$ as long as long as wide, anterior part of nervellus strongly inclivous....................... Nepiesta hungarica Szépligeti, 1916

- Antenna with 26-28 flagellomeres, area superomedia $2 \times$ as long as long as wide, anterior part of nervellus vertical ......... .. Nepiesta rasnitsyni Kasparyan, 2011

9. Pterostigma yellowish, metasoma entirely to predominantly dark 10

- Pterostigma brown, metasoma dark with brownish bands ..11

10. Hind tibia externo-medially creamy yellowish Nepiesta tibialis Horstmann, 1977

- Hind tibia externo-medially reddish brown Nepiesta mandibularis (Holmgren, 1860)

11. Malar space shorter than basal with of mandible, mesoscutum and mesopleuron rather sparsely punctate, punctures separated from each other by usually more than a puncture diameter, dark apical band of hind tibia longer than wide....................... Nepiesta subclavata Thomson, 1887

- Malar space as long as basal with of mandible, mesoscutum and mesopleuron rather densely punctate, punctures separated from each other by usually less than a puncture diameter, dark apical band of hind tibia very narrow...

Nepiesta tricingulata Horstmann, 1973

\section{Biogeography}

The first records of Eriborus obscuripes Horstmann, 1987 from Romania, Eriborus terebrator Aubert, 1960 from Hungary and Spain, Nepiesta mandibularis (Holmgren, 1860) from Hungary and Romania, Nepiesta rufocincta Strobl, 1904 from Romania, and Nepiesta tibialis Horstmann, 1977 from Turkmenistan are reported below. 


\section{Eriborus obscuripes Horstmann, 1987}

Material. Romania, Arad County, Ineu [on label: Borosjenö], 13.VI.1927, collector unknown, 1§. - Romania, Cluj County, Ocna Dejului [on label: Désakna], date unknown, leg. E. ZilahiKiss, $1{ }^{\widehat{O}}$.

Remarks. First records for Romania. This species was previously known from several Western and Middle European countries; these Romanian records represent its easternmost occurrence $(\mathrm{Yu}$ et al. 2012).

\section{Eriborus terebrator Aubert, 1960}

Material. Hungary, Budapest, 18th District, Kossuth Street, IX.2014, leg. V. Szöke, 1ㅇ. Spain, Catalonia, Province of Lleida, $6 \mathrm{~km} \mathrm{E} \mathrm{of}$ Bassella Ogern, 13-14.V.2003, leg Gy. \& I. Rozner, 1 ㅇ.

Remarks. First records for Hungary and Spain. This species was known from France, Bulgaria and Italy so far (Yu et al. 2012, Di Giovanni \& Reshchikov 2016).

\section{Nepiesta mandibularis (Holmgren, 1860)}

Material. Hungary, Budapest, Csepel, date 11. IV.1895, leg. Gy. Szépligeti, 3ㅇ. - Hungary, Budapest, Svábhegy, IV.1895, leg. Gy. Szépligeti, 1ㅇ․ - Hungary, Somogy County, Babócsa, 7.IV.2001, leg. unknown, 1 $9 .-$ Romania, Mureș County, Saschiz [on label: Kaisd-Saschiz], date unknown, leg. Silbernagel, 10 .

Remarks. First records for Hungary and Romania. This species has been known from several countries of the Palaearctic region ( $\mathrm{Yu}$ et al. 2012).

\section{Nepiesta rufocincta Strobl, 1904}

Material. Romania, Bistrița-Năsăud County, Rodna Mts, Vârful Ineu (= Ineu Peak) [on label: Radnai-havasok, Ünőkő], 17.VII.1908, leg. E. Csiki, 1 ㅇ․
Remarks. First record for Romania. This species has been known from Austria, France, Germany, and Poland so far; this Romanian record represents its easternmost occurrence ( $\mathrm{Yu}$ et al. 2012)

\section{Nepiesta tibialis Horstmann, 1977}

Material. Turkmenistan, Kopet Dagh Mts, 6 km W of Germob, Kurkulab, 850 m, 19.IV.1993, leg. M. Hreblay, Gy. László \& A. Podlussány, No. L89, 1 ㅇ.

Remarks. First record for Turkmenistan (and, hence, for the Eastern Palaearctic region). This species has been known only from Jordan so far (Yu et al. 2012).

Acknowledgements - I am grateful to Maria Tavano (Museo Civico di Storia Naturale "Giacomo Doria", Genova), Anne Freitag and Marion Podolak (Cantonal Museum of Zoology, Lausanne), Gavin Broad (Natural History Museum, London), and James Brooke (Bernice Pauhai Bishop Museum, Honolulu) for their help in checking relevant type materials. I thank Tamás Németh and Zoltán Soltész (HNHM, Budapest) for the photos.

\section{REFERENCES}

AUBERT, J.F. (1977): Nouvelle série d'Ichneumonides pétiolées inédites. Bulletin de la Société Entomologique de Mulhouse, 1977: 1-8.

CAMERON, P. (1907): On the parasitic Hymenoptera collected by Major C.G. Nurse in the Bombay presidency. Journal of the Bombay Natural History Society, 17(3): 578-597.

CheEsman, L.E. (1936): Hymenoptera of the New Hebrides and Banks Islands. Transactions of the Royal Entomological Society of London, 85(7): 169-195. doi: 10.1111/j.1365-2311.1936.tb00131.x

CHOI, J.-K. \& LEE, J.-W. (2010): Taxonomic study of Korean Eriborus Förster (Hymenoptera: Ichneumonidae: Campopleginae) new to Korea. Entomological Research, 40: 236-241. doi: 10.1111/j.1748$\underline{5967.2010 .00287 . x}$

Di Giovanni, F. \& ReshChIKov, A. (2016): Contribution to the knowledge of Ichneumonidae in Italy. Linzer biologische Beitrage, 48(1): 495-505. doi: 10.4081/BollettinoSEI.2014.41 
FULLAWAY, D.T. (1940): New species from the Bishop Museum collection of Samoan parasitic Hymenoptera. Proceedings of the Hawaiian Entomological Society, 10: 399-410.

GAULD, I.D. (1991): The Ichneumonidae of Costa Rica, 1. Introduction, keys to subfamilies, and keys to the species of the lower Pimpliform subfamilies Rhyssinae, Poemeniinae, Acaenitinae and Cylloceriinae. Memoirs of the American Entomological Institute, 47: 1-589.

GAUld, I.D., WAHL, D., BRADShaW, K., HANSON, P. \& WARD, S. (1997): The Ichneumonidae of Costa Rica, 2. Introduction and keys to species of the smaller subfamilies, Anomaloninae, Ctenopelmatinae, Diplazontinae, Lycorininae, Phrudinae, Tryphoninae (excluding Netelia) and Xoridinae, with an appendix on the Rhyssinae. Memoirs of the American Entomological Institute, 57: 1-485.

HorstmanN, K. (1973): Revision der Gattung Nepiesta Förster (mit einer Übersicht über die Arten der Gattung Leptoperilissus Schmiedeknecht) (Hymenoptera, Ichneumonidae). Polskie Pismo Entomologiczne, 43: 729-741.

HorstmanN, K. (1977): Campopleginae aus Jordanien und Libanon (Hymenoptera, Ichneumonidae). Annales historico-naturales Musei nationalis hungarici, 69: 195-199.

HorstmanN, K. (1987): Die europäischen Arten der Gattung Echthronomas Förster and Eriborus Förster (Hym., Ichneumonidae). Nachrichtenblatt der Bayerischen Entomologen, 36: 57-67.

JonAtHAN, J.K. (1999): Hymenoptera: Ichneumonidae. Fauna of West Bengal. Part. 8. Insecta (Trichoptera, Thysanoptera, Neuroptera, Hymenoptera and Anoplura). Zoological Survey of India, Calcutta, $442 \mathrm{pp}$.

KASPARYAN, D.R. (1981): A guide to the insects of the European part of the USSR. Hymenoptera, Ichneumonidae. 11 Ctenopelmatinae. 12 Phrudinae. 13 Tersilochinae. 14 Cremastinae. 15 Campopleginae. 16 Ophioninae. Opredeliteli Fauny SSSR, 3(3): 316-431.

KASPARYAN, D.R. (2011): Two new ichneumonid species of the genera Callidora Förster, 1869 and Nepiesta Förster, 1869 (Hymenoptera: Ichneumonidae: Campopleginae) from Russian Far East. Russian Entomological Journal, 20(3): 287-290. doi: 10.15298/rusentj.20.3.11
Khalaim, A.I. \& KASPARYAN, D.R. (2007): Subfamily Campopleginae. In. LELEJ, A.S. (Ed.) Key to the insects of Russia Far East. Vol. IV. Neuropteroidea, Mecoptera, Hymenoptera. Pt 5. Dalnauka, Vladivostok, p. 597-632.

MomoI, S. (1970): Ichneumonidae (Hymenoptera) of the Ryukyu Archipelago. Pacific Insects, 12(2): 327-399.

Morley, C. (1913): The fauna of British India including Ceylon and Burma, Hymenoptera, Vol.3. Ichneumonidae. British Museum, London, 531 pp.

MÜLLER, F.P. (1950): Über Schadauftreten und Biologie von Colaphellus sophiae Schall. (Chrysomel.). Zeitschrift für Angewandte Entomologie, 31: 591-608.

Olson, D.M., Dinerstein, E., WiKRAMANAYAKE, E.D., Burgess, N.D., Powell, G.V.N., UnderWOOD, E.C., D'AMico, J.A., ITOUA, I., StRAND, H.E., MORrison, J.C., LOUCKS, C.J., AllnutT, T.F., RicKeTTS, T.H., KURA, Y., LAMOREUX, J.F., Wettengel, W.W., Hedao, P. \& Kassem, K.R. (2001): Terrestrial ecoregions of the world: a new map of life on Earth. Bioscience, 51(11): 933-938. doi: 10.1641/0006-3568(2001)051[0933:TEOTWA]2.0. $\underline{\mathrm{CO} ; 2}$

Paull, C. \& Austin, A.D. (2006): The hymenopteran parasitoids of light brown apple moth, Epiphyas postvittana (Walker) (Lepidoptera: Tortricidae) in Australia. Australian Journal of Entomology, 45(2): 142-156. doi: 10.1111/j.1440-6055.2006.00524.x

RuEdA, M., Rodríguez, M.Á., \& HAWKInS, B.A. (2013): Identifying global zoogeographical regions: lessons from Wallace. Journal of Biogeography, 40(12): 2215-2225. doi: $10.1111 /$ jbi.12214

ŠEDIVÝ, J. (1963): Taxonomischer Beitrag zur Gattung Eripternus Foerst. (Hym., Ichneumonidae, Ophioninae). Casopis Ceskoslovenske Spolecnosti Entomologicke, 60: 280-283.

TosquinET, J. (1903): Ichneumonides nouveaux. (Travail posthume). Mémoires de la Société Entomologique de Belgique, 10: 1-403.

TOWNES, H. (1969): The genera of Ichneumonidae. Part 1. Memoirs of the American Entomological Institute, 11: 1-300.

TOWNES, H. (1970): The genera of Ichneumonidae. Part 3. Memoirs of the American Entomological Institute, 13: 1-307. 
TOWNES, H., TOWNES M. \& GUPTA, V.K. (1961): A catalogue and reclassification of the Indo-Australian Ichneumonidae. Memoirs of the American Entomological Institute, 1: 1-522. doi: $\underline{10.1093 / \mathrm{besa} / 8.2 .93 \mathrm{~b}}$

VACHAL, J. (1907): Note sur les Hyménoptères de la Nouvelle-Calédonie. Revue d'Entomologie, 26: $118-123$.
YU, D.S. \& Horstmann, K. (1997): A catalogue of world Ichneumonidae (Hymenoptera). The American Entomological Institute, Gainesville, pp. 1558.

Yu, D.S., van AChTERBerg, C. \& Horstmann, K. (2012): Taxapad 2012, Ichneumonoidea 2011. Database on flash-drive. www.taxapad.com, Ottawa, Ontario. 